\title{
戸建て住宅地におけるコモンスペースの緑の管理による 街なみとコミュニティ形成 \\ A STUDY ON LANDSCAPE AND COMMUNITY DEVELOPMENT THROUGH GREEN MANAGEMENT OF COMMON SPACES IN DETACHED HOUSING AREAS
}

\author{
齊藤広子* \\ Hiroko SAITO
}

\begin{abstract}
This study aims at examining effects of green management of common spaces for formulating community and landscape development in detached housing areas. The study clarifies the following points through the results of questionnaire survey to the residents and observation survey. In detached housing areas, through maintenance of the green in common spaces, residents mutually look at neighbors' face, exchange greetings to neighborhood and support to maintain the green in common spaces. The community has closed friendship through cooperative maintenance of the green. A cooperative maintenance of green in common spaces strengthens residents' community, resulting in contributing to formulate a better landscape in the areas.
\end{abstract}

Keywords: Detached Housing Area, Common Space, Green, Management, Community, Landscape 㝎建て住宅地コモンスペース、緑、管理、コミュニティ、街なみ

\section{1. 研究の背景と目的}

最近、計画的戸建て住宅地においてコモンスペースがつくられる ようになってきている1”。コモンスペースがつくられる背景は、道 路率を下げ、宅地面積を増やしながらも各住宅の日照・通風を確保 するためという侧面もあるが、その一方では個性や魅力ある街なみ、 ユミュニティ形成のために、より質の高い住墂境形成を目指し導入 されることがある2)。

コモンスペースにはいろいろな空間形態 ${ }^{3)}$ 、そして所有形隹があ る か、著者は戸建て住宅地の住環境を居住者が共同で管理するシ ステムを整備することが重要であると考えており、そのため「『管 理の共同化』が必須条件となる」という視点から共有空間としてつ くられたコモンスペース及びそのコモンスペースがある戸建て住宅 地に特に注目し研究を進めてきた。

その結果、コモンスペースを共有空間としてつくるだけではより 質の高い街なみ形成やコミュニティの育成には寄与せず、そこに共 有のものがあり、それを居住者が共同で管理するこ之を通じてコミ ユニティの䏍成や街なみ形成に寄与することを明らかにしてきだ!。 そして、そのキーとなるのは「緑」ではないかという仮説をもつよ うになった。共有空間としては道路や公園・㕕場、集会所などがあ り、そこには梯々な共有物がある。それらの管理には維持保全・修
縉、連営などの様々な行為が必要となる。そのなかで居住者が日常 的に管理を行い、その成長や変化を日々楽しむことができる身近な 共有のものとして「緑」がある。共有の緑を居住者が共同で管理す ることを通じて、よりよい街なみ形成が可能となり、コミュニティ も育成されるのではないだろうか。

そこで本研究ではコモンスペースの緑はどのように街なみ形成に 寄与するのか、居住者はコモンスペースの緑をどのように考え、そ してどのような場合に緑は良好に管理され、居住者はより積便的に 管理を行おうと考えるのか、さらには緑の管理を通じて居住者のコ ミュニティが形成されるのかを明らかにする。

\section{2. 研究の方法}

・コモンスペースの绿：コモンスペースの緑とは共有瑩間としてつ くられたコモンスペース内にある木・草花などをさす。各住宅のプ ランターや植木䤲などが共有空間内に置かれることもあるが、ここ では共同の管理の対象物になる共有の緑、特に「木」に注目し分析 を行う。

\section{・研究の仮説（図1）：}

(1)コモンスペースの緑の管理は、緑の整備状熊、具体的にはコモン スペースにどのような杖どれだけあるかという木の量や質によっ 
て、管理の負担が異なることから、その状態が異なってくる。木の 量が多く、管理がしにくい木が多い場合には管理が行き届きにくく なる。

(2)粶の管理方法によっても管理状態が異なってくる。木の剪定・薬 郕散布や下草の手入れ、落葉拾いなどをどのように行うのか、担当 者や手入れの頻度によっても異なってくる。

(3)モンスペースの緑の管理を共同で行うためには居住者間のコミ ュニティが必要となる。そこで、コミュニティが良好な状態である 場合には管理が良好に実施される。さらに共同で管理することを通 じて居住者間のコミュニティが育成する。

(4)管理が良好に行われることにより、より良好な街なみが形成され る。街なみが良好な状態であると、居住者はそれを維持したいと、 管理により積極的になり、緑の管理状態が良くなる。

・調查対象住宅地の塄定と概要（表 1 . 表 2. 図2.表3）：

(1)共有空間としてコモンスペースがあり、そこに共有の「木」があ る戸建て住宅地を対象とする。

(2)戸建住宅地において共有空間としてつくられるコモンスペースは 区画内道路」「広場・小公園」「集合駐車場」が多い。共有空間 が主に区画内道路である住宅地を「道コモン型」、共有㠰間が主に 広場・公園である住宅地を「迅場コモン型」、共有空間が主に集合 駐車場である住宅地を「駐車場コモン型、とタイプわけすると、こ こでは「駐車場コモン型」を対象とする。その理由は以下の通りで ある。

「駐車場コモン型」では集合駐車場を中心とした小広場を 5〜 6 件、多くても10件程の住宅で用むようになっている。その小広場は 駐車スペースとしての利用以外に、車肪駐車していない暘合には子 供の遊び場等として利用することが意図されている。「駐車場コモ ン型」では、その小広場（以下、コモンスペースと呼ふ）を利用す る人はコモンスペースに縢接する住宅の居住者に概小限定されてお り、そこにある木の管理担当者は隣接する住宅の居住者が中心とな る。

一方、共有空間が道路や広場・公園などの道コモン型や広場コモ ン型では、共有空間はそれに接する住宅の居住者のみで利用され るわけではない。また共有空間でつくられたコモンスペースは陆接 住宅の居住者のみで所有されているわけでもないため、管理担当者 の範囲が明確になっておらず、限定されていない。

そこで、利用者である居住者どうしのコミュニティの状態による 各コモンスペースの緑の管理状態の相違をみるには、駐車場コモン 型のコモンスペースのように共有空間の範囲、利用者、管理担当者 が明確でかつ限定、いいかえると特定化されているものが最も適切 となる。

(3)駐車場コモン型の戸建て住宅地のなかでも、調査対象住宅地の選 定は、コモンスペースの木の量が異なる住宅地を含めるようにする （表 3）。木の量は管理のしにくさを考虑し低木は含めないで、中 木と高木の数とする。その際、木の量はコモンスペースの広さによ
って密度が異なることから、コモンスペースの広さの違いも考慮し、 選定する。

(4)コモンスペースに木が多い住宅地としてはA・C住宅地、少ない 住宅地としてはB・D住宅地を選定した。コモンスペースが広い住 宅地としてはA・B住宅地、狭い住宅地としてはC・D住宅地であ る。つまり、A住宅地はコモンスペースが広く、緑が多い住宅地、 B住宅地はコモンスペースが広く、緑が少ない住宅地、C住宅地は コモンスペースが狭く、緑が多い住宅地、D住宅地はコモンスペー スが狄く、緑が少ない住宅地である。

調查の方法：上記の仪説を娭証するために、以下の二つの調査を 実施した。

(1)居住者アンケート調査 : 居住者のコモンスペースの緑の評価、共 同管理の方法之評価、街なみの評価、近腾つきあいを把握するため に居住者アンケート譑榃を実施した。調査は直接訪問配付・留置自

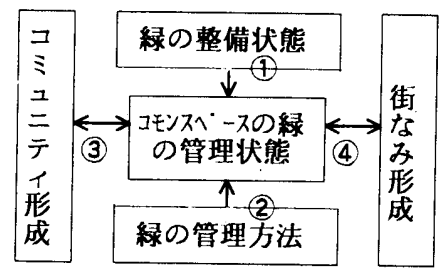

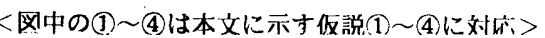

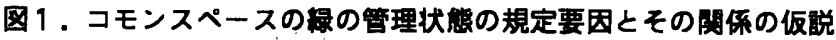

表 1 . 睭查対象住宅地の概要とアンケート眮査配付 - 回収状況

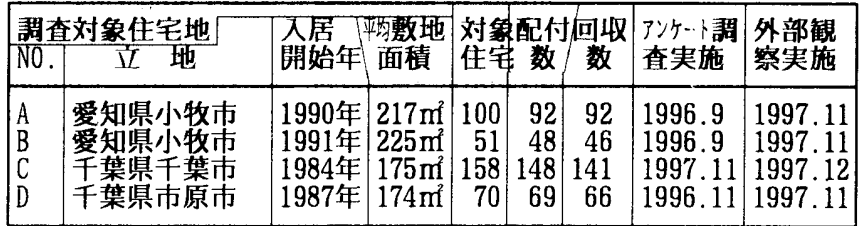
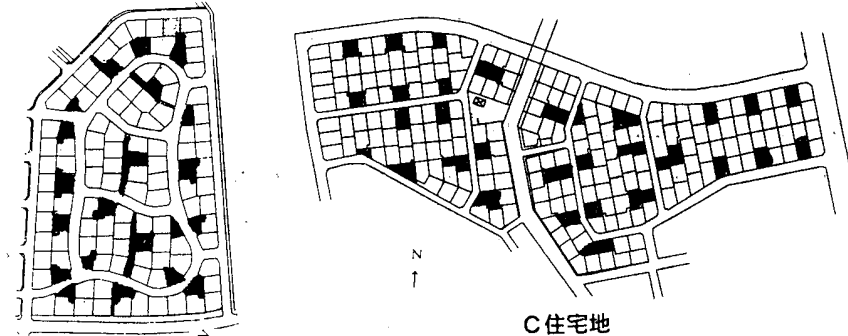

C住宅地

A 住宅地
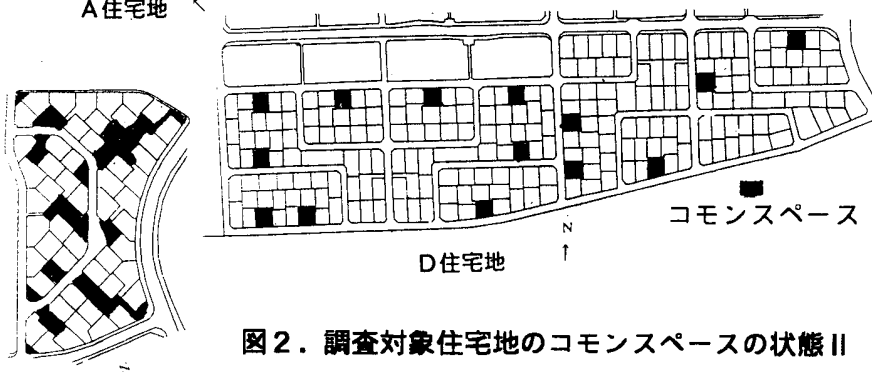

D住宅地

図 2．調查対象住宅地のコモンスペースの状告川

表 2. 調查対象住宅地のコモンスペースの状甞 |

B住宅地

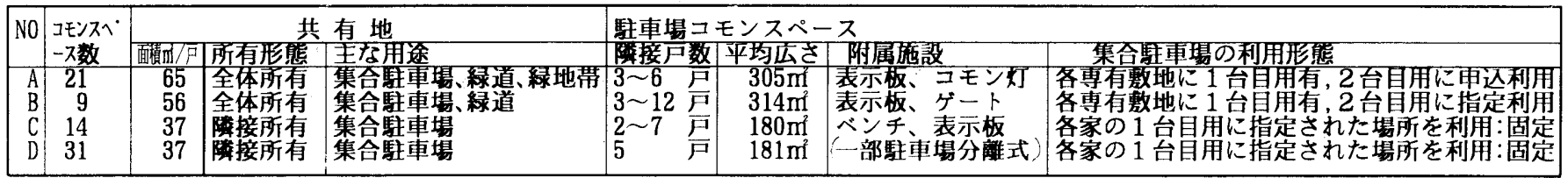


記入後・直接訪問回収する方法で1996年 9月〜11月、1997年11月に 実施した。対象住宅数 379、配付数 357、回收数 345、回收率96.6 \%である。

(2)外部熘察調査 : 調查対象住宅地のコモンスペースの緑の管理状態 を把握するための外部観察調査を行った。調査は1997年11〜12月に 実施した。

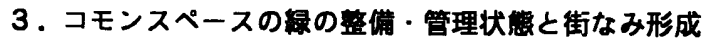

コモンスペースの緑の整備、管理状態がどのように街なみに影墼 を与えるのかをみる。街なみへの影墼としてここでは居住者が街な みをどのように評価しているのかという「街なみ評価」をとりあげ る。

\section{1 コモンスペースの䟿の整偏状繁と街なみ評価}

コモンスペースの緑の整備状態として、集合駐車埸を含む小広場 の木の量は、コモンスペースが広いわりには木が少ないB住宅地を 基準とすると、コモンスペースの木の量はA住宅地は約 2 倍、C住 宅地は約 3倍、D住宅地はほぼ同じである（表 3）。しかし、C． D住宅地はコモンスペースが狭いことを考虑すると、C住宅地は $\mathrm{B}$ 住宅地の密度当たり約 4 倍の木の量、D住宅地でも約 1.5 倍之なっ ている。C住宅地は 1 コモンペースあたりの木の量、密度当たり の木の量共に対象住宅地のなかで最も粶が多い住宅地である。

コモンスペースの木の量によって居住者のコモンスペースの苹価 が異なるかをみる亡、コモンスペースに杖多い住宅の居住者が必 ずしもコモンスペースを高く評価しているとは限らない（図3）。

コモンスペースの木の密度別にみると、木の密度が高いからとい って必ずしもコモンスペースの評価が高いわけではない（図4）。

住宅地の街なみ評価がコモンスペースの木の量によって異なるか をみると、コモンスペースに杖多い住宅地の居住者が必ずしも街 なみを高く評価しているとは限らない（図5）。

コモンスペースの木の密度別にみると、木の密度が高いからとい って必ずしも街なみの評価が高いわけではない（図6）。

このようにコモンスペースに杖多いからといって単純に居住者 のコモンスペースの評価、そして住宅地の街なみの評価が高くなる という傾向はみられない。

\section{2 コモンスペースの绿の管理状能と街なみ評洒}

\section{・绿の管理方法（表 4.5)}

コモンスペースの緑をどのように管理しているのか、管理の状態 は緑の管理方法によって異なることが考えられる。

調榃対象の 4 住宅地とも駐車場コモン型の住宅地であるが、A . B住宅地はコモンスペース全体を住宅地全体で所有し、木の消毒や 剪定は業者に委託し、日常的な清据・手入れは居住者が一斉に行う 方法がとられている。C・D住宅地では各コモンスペースは各コモ ンスペースに腾接している住宅で所有し、管理は各コモンスペース ことに行うことになっている（表 4)。

表 4.コモンスペースの管理方法 |
表 3 . コモンスペースの木の量

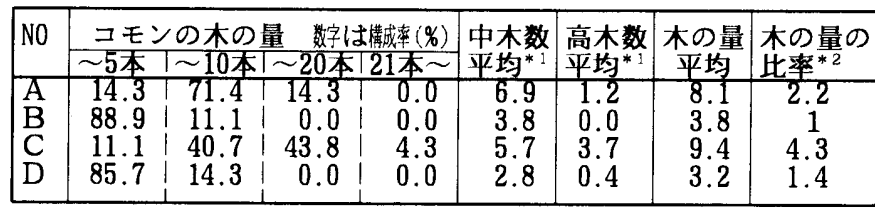

*1 中木之高木の定義は管理 · 手入れのしやすさを考慮し 中条は人の背の高さや增を超え2 階の空に届く程度 $(2 \sim 6 \mathrm{~m})$ の木 高木は2 階の些を超える高さ (6m以上)の木 とした

人の背までの高さの木は低条とし、ここでは含めていない。

*2 コモンスペースの広さを一定にした場合の木の量の比率 木の量が最も少ないB住宅地を1にした割合

\section{コモハスイース木の本数 \\ $0 \sim 5$ 本 26.7 .

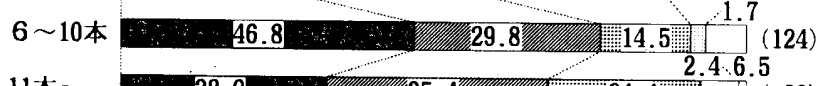

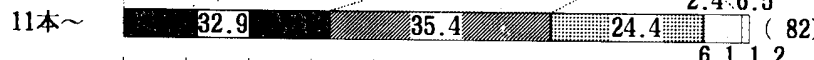

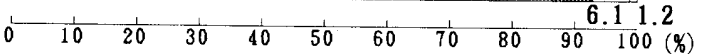

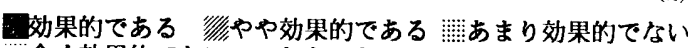 全く効果的でない 口わからない}

図3. 木の贯別にみたコモンスペースの評価|ー木の本数 ーコモシスペースは美しい街なみや住環境に好果的かー

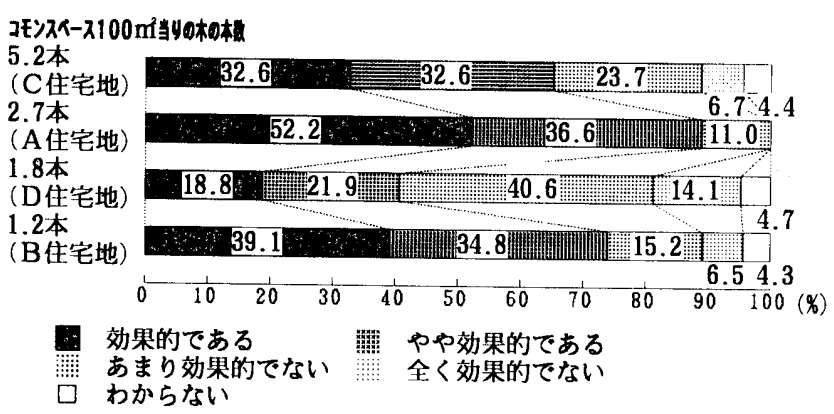

図4.木の年別にみたコモンスペースの評価川ー木の密度 ーコモンスペースは美しい街なみや住環境に効果的か一

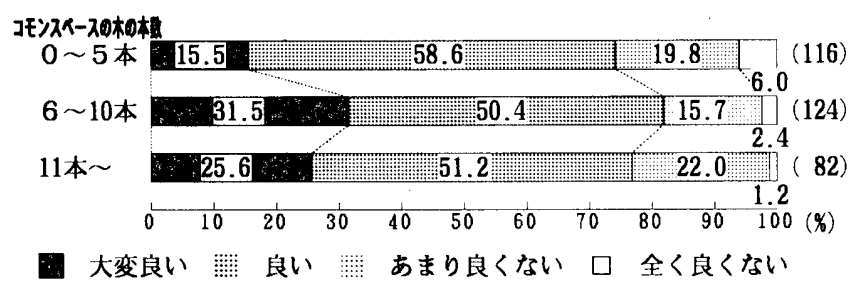

図5.木の量別にみた街なみの評価 I一木の本数 一自分の往んでいる住宅地の街なみは?

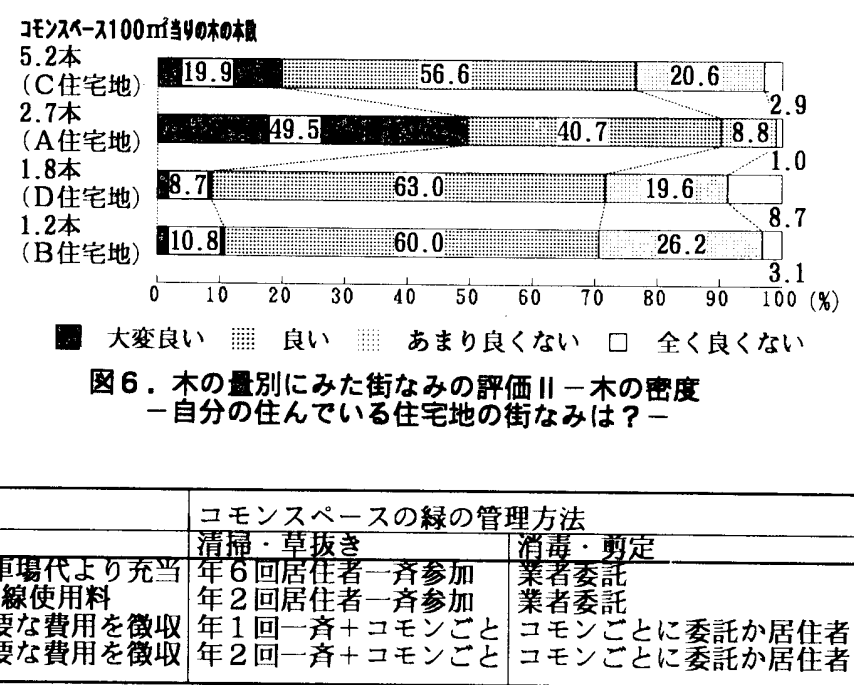


C 住宅地はコモンスペースの木の量が最も多い。ここでは年 1 回 の住宅地全体の一斉清掃が行われ、それ以外は各コモンスペースこ とで個別に手入れを行うことになっている。そのため、同じ住宅地 であっても異なる管理方法が取られることがある。そこで、C住宅 地を取り上げてコモンスペースの管理方法をみる（表5）。

コモンスペースの緑の水やり・草取り・木の枝の剪定・落葉拾い などの管理はどこでも気がついた居住者が気がついた時に行う方法 (随時) が最も多い。木の剪定や病虫害の駆除に関しては「業者、 に委託するケースもある。しかし、居住者が主体となり管理を行う ことに程度の差があれほとんど違いはみられない。

$\mathrm{C}$ 住宅地の場合に、各住宅が共有空間の緑の手入れのために年間 どのぐらいの費用をかけているかをみると、コモンスペースにより 違いはみられるが、5000円未満が約 8割と多く、5000円〜 1 万円か 約 2割である（図7）。

管理への居住者の参加の仕方は一斉に皆で行う際や当番の時のみ に参加する人が約15\%で、その他の人は気が付いた際にも何等かの 手入れを行っている（図8）。

そのため手入れを行う回数は居住者により異なり、多い人は每日、 少ない人は 1 年に 1 回程度で、月 1 回程度行う人が最も多い(図 9)。

\section{・的の管理状管}

次に共有空間であるコモンスペースの緑の管理状態をみる。緑の 管理状態として、木をきちんと剪定し、枯らしていないかなどの

「木の手入れ」の状熊之、雓草や芝生が伸び放題になっていないか などの「下草の手入れ」の状態についてみる（表 6）。

良好に管理がされているのは、木の手入れに関してはA・C・D 住宅地に多い。下草の手入れはA・D住宅地で良好な場合が多い。

つまり、全体で管理しているA・B住宅地と、各コモンごとの管理 であるC・D住宅地では管理方法が異なるが、管理方法による明碓 な違いはみられない。しかし、管理を業者委託し、居住者参加の機 会が少ないB住宅地は木・下草ともに手入れの状態が良くない。

\section{・绿の管理状態と街なみ訊価}

緑が良好に管理されている場合には街なみ形成に寄与しているの であろうか。緑の管理状態と居住者の街なみ評価をみる上、緑が良 好に管理されている場合には居住者の街なみ評価が高い（図10）。

\section{3 管理の状蕧の規定要因（図11）}

緑の管理状態が良い場合に居住者の街なみ評価が高くなっている が、どのような場合に緑の管理が良好に行われているのであろうか。

緑の管理状態は「管理方法」による相違は明碓にはみられなかっ た。そこで、「緑の整備状態」「コミュニティの状態」「街なみ形 成の状態」により管理状態がどのように異なるかをみる。

緑の整備状態からみると、コモンスペースの木の量が少ない湯合 には管理の手間がそれほどかからず、手入れが行き届きやすいと考 えられる。そこで、木の本数と管理の状態をみると、木の本数が少 ないちが管理の状態が良い場合が多い。

居住者のコミュニティの状態を「近腾つきあい,の状態でみると、 近婘と親しくつきあっている人が多い場合には良好に管理されてい ることが多い。

街なみ形成の状態を居住者の「街なみ評価」でみると、街なみの 評価が高い人が多い場合に良好に管理されていることがやや多い。
表5.コモンスペースの管理方法II．－Ｃ住肎地の场合一

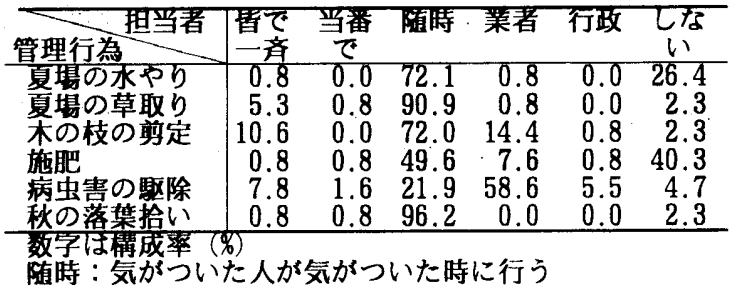

4.81 .11 .1

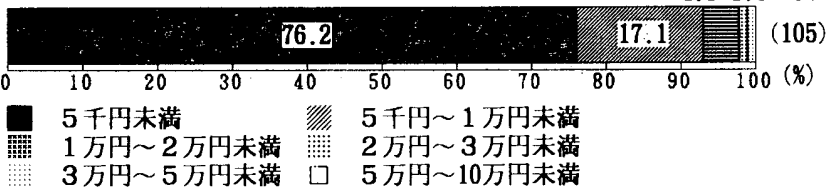

図 7.コモンスペースの绿の管理の各家庭の年間表用

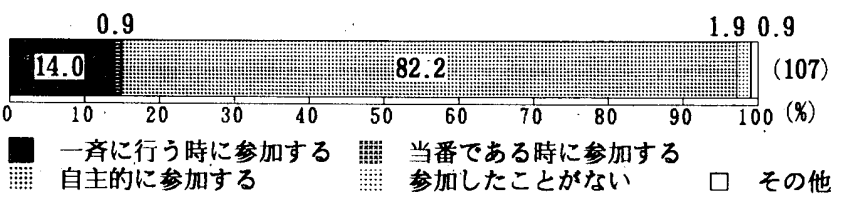

図8．コモンスペースの縟の管理の加の仕方

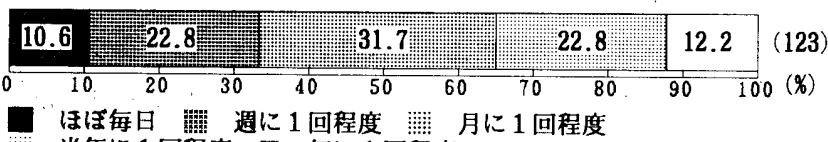

半年に 1 回程度 $\square$ 年に 1 回程度

図9.コモンスペースの緑の管理の参加の頻度

\section{表 6 .綅の管理の状態}

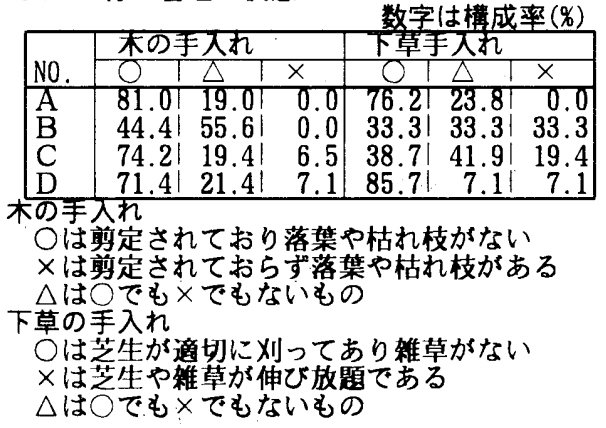

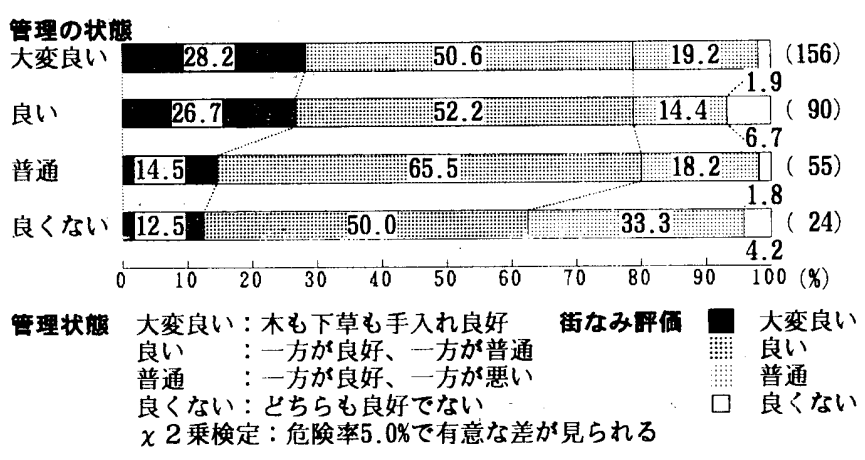

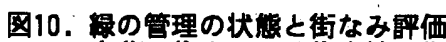
一自分の惟んでいる住宅地の街なみは? - 


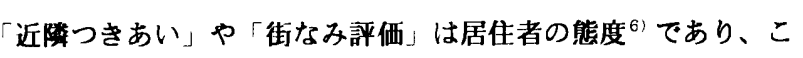
のような居住者の個人の態度により地域の行動傾向が規定される側 面がある。しかし、居住者㑑人の態度の全ての項目がそのままコモ ンスペースの緑の管理状態に影第を与えるわけではない。例えは、、 居住者のコモンスペースの緑の管理負担感をみる之、居住者の負担 感によるコモンスペースの緑の管理状態に大きな相違はみられない。 このようにコモンスペースの緑の管理状態は個人の感情による影響 をうけにくい側面がある。

そして、居住者が管理組合の存在や組合がない場合には共同管理 の必要性を入居時から認知している人が多い埸合にはコモンスペー スが良好に管理されていることが多い。組合活動などの共同管理を 睡入時から評洒している人が多い場合もコモンスペースが良好に管 理されていることが多い。現在の組合活動の評価による違いはあま りみられず、組合の評価を「良くない」と回答している以外が多い 易合にはコモンスペースが良好に管理されていることが多い。この ように、居住者か共同管理の意義や必要性を理解している場合には コモンスペースの緑は良好に維持されている。

コモンスペースの粶の管理は、居住者個人の感情に規定されるよ りも、それを共有する居住者か、、良好な街なみ形成という価值を共 有し、それを実現するためには共同管理が必要であるという考えを 共有し、居住者間の近陆つきあいを深めるという、コミュニティが 形成されることにより良好に管理されている。

\section{4.绿の管理によるコミュニティの形成}

コモンスペースの緑を良好に管理していくには、居住者が近陆つ きあいを深めると共に、共同化への理解、価値の共有化が必要にな る。

粶の管理はそういったコミュニティ形成に寄与しているのであろ うか。ここではコミュニティを「近绦つきあい」「価值の共有化」

「目漂の共有化」という三つの侧面からみる7?。

緑が最も多いC住宅地をとりあげてみる。

\section{1 绿の管理を通しての近睡つきあいの变化}

共有空間のコモンスペースの粶の管理を通じてのコミュニティ形 成として、近腾つきあいがどのように変ったか、その変化をみる。

緑の管理・手入れを通じて近腾つきあいに変化がないという人も 䄪 2 割いるか、「緑の手入れをするご近所の人をみかける」「緑の 手入れをするこ近所と挨拸をする」という認知的な近陆つきあいる) をより育成している場合が約 6割である。さらに、より親しくなる というような相互扶助的な近陆つきあいを育成している場合が約 2 割である(図12)

それでは次によ゙のような場合に近陆つきあいが変化しているので あろうか。緑の手入れの機会が多いほ亡、緑の管理による近腾つき あいが梁まるのではないか、緑の手入れの参加の仕方之参加の頻度 の違いをみる（図13）。結果、一阇清掃のように決まった時に参加 をしている人（義務参加）よりも、自主的に随時気が付いた時に粶 の手入れを行っている人（自主参加）の方がュモンスペースに滞在 する機会が多くなるため、緑の管理を通じて近陆の姿や挨猡を交わ すことが多く、より親しくなる人がやや多い。しかし、一斉清掃の ような義務的な参㸝のみの場合でも近陆つきあいは変化している。

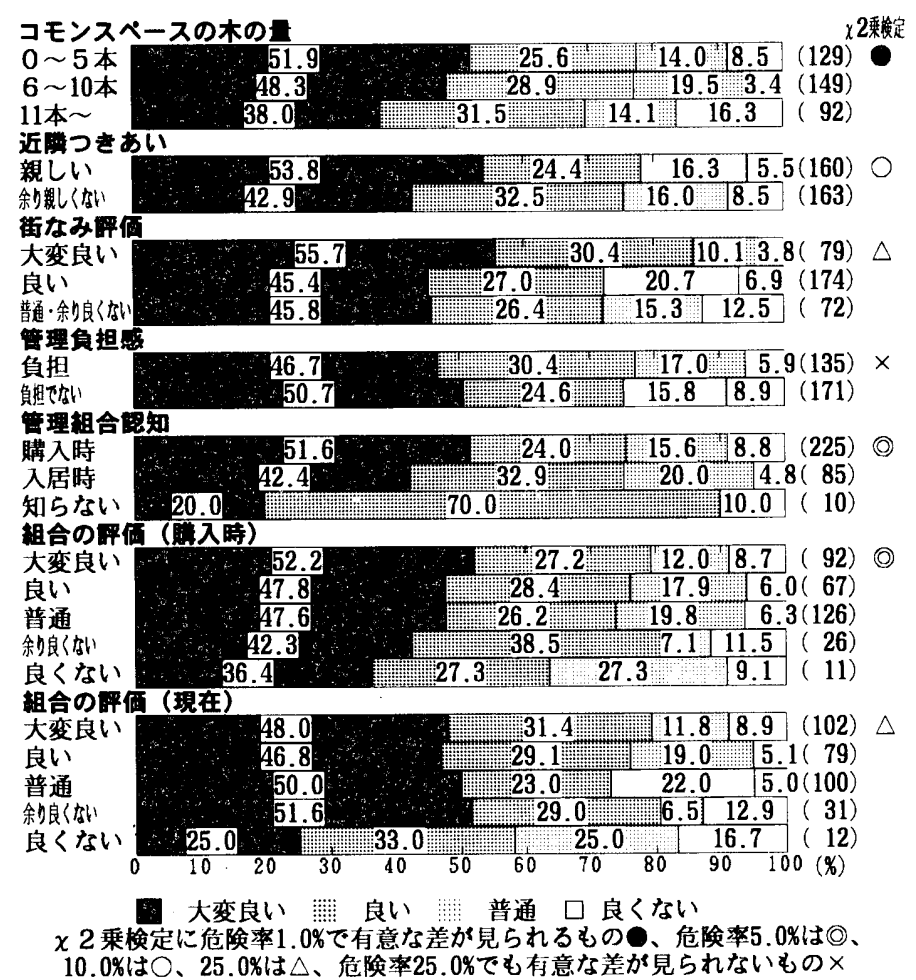

図11. 绿の管理の状態の規定要因

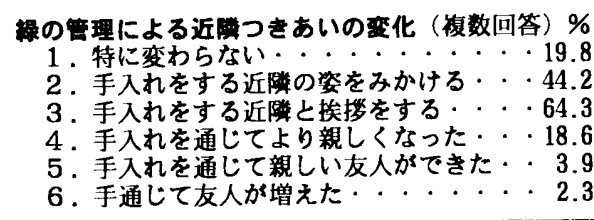

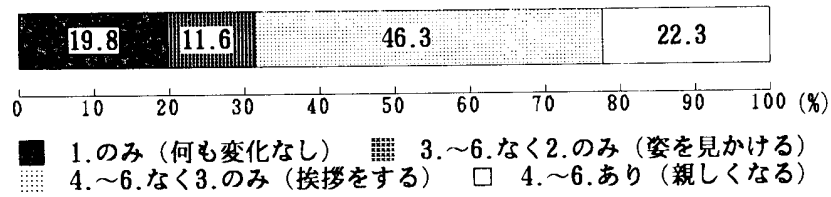

図12、緑の管理による近䑏つきあいの变化।

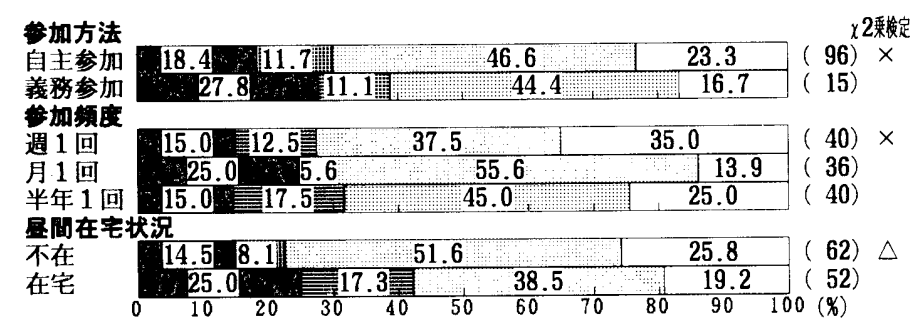

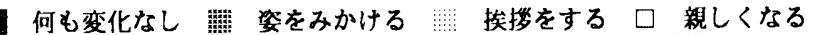
$\chi 2$ 乗検定に危険率1.0\%で有意な善が見られるもの○、危険率5.0\%は○、 10.0\%は○、25.0\%は $\triangle$ 、危険㽜 $25.0 \%$ も有意な差が見られないもの

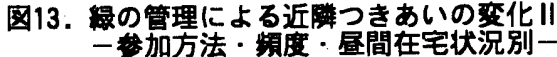

緑の管理・手入れへの参加の方法や頻度による近倩つきあいの変化 に明確な違いはみられない。そして、緑の手入れを通じての近陆つ きあいは日常的に近陰う機会が少ない居住者の方に変化がみら 
れる。つまり、日頃仕事などで昼間誰も在宅していない住宅では近 陆之知合う機会は少ないが、一斉清掃に参加するなど緑の手入れに 参加することを通じて近隣䦥係が梁まる傾向がややみられる。

このようにコモンスペースの緑の手入れ・管理はどのような形態 で参加するかにかかわらず、居住者の近陆つきあいに変化を与える きっかけになり、緑の手入れを通じて近腾のつきあいに変化がみら れる（図14）

娽の管理による近監つもあいの变化

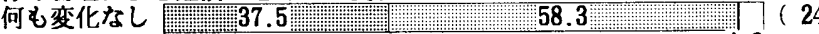

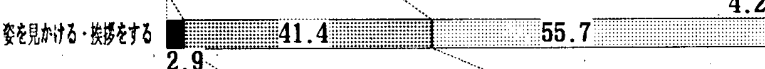
親しくなる (70) $\begin{array}{llllllllllll}0 & 10 & 20 & 30 & \frac{1}{10} & 50 & 60 & 70 & 80 & 90 & 100 & (\%)\end{array}$ 互以に行き来する 洋家族や盘味の話をする 挨萝を交わす程度である 口ほとんどつきあい $\chi 2$ 乗検定：危険率5.0\%で有意な差が見られる

図14、程の管理による近隣つきあいの变化別 現状の近嗼つきあい

\section{2 コモンスペースの䋚の評価}

緑の管理によるコミュニティ形成の状態を、「コモンスペースの 緑をどのように評価しているのか。共有の財産と考えているか」と いう価値の共有化の視点からみる。

コモンスペースの緑について、緑の様々な効用を考えて質問項目 を設定した ${ }^{91}$ 結果、肯定的な評価としては「季節感を感じる」「景 観が良い」「心の安らぎ・淍いを感じる」などが多い。否定的な評 価としては「手入れが大変」「落葉が多く、手入れが大変」という 管理面の負担についてが多い。居住者のなかで肯定的な評価のみ回 答した人は約 4 割、肯定的な評価とともに否定的な評価を回答した 人は約 5 割、否定的な評価のみの人は約 1 割である（図15）。肯定 的な評価のみ回答した人は緑の管理を負担に感じていない人であり、 逆に否定的評価の回答が多い人は管理を負担に感じている人である。

居住者が緑をどのように評価するのか、その評価は、木の本数之 いった緑の整備状熊の違い、子供や高跲者がいるなどの家族構成の 違いよりも、コモンスペースをよく利用するといったコモンスペー スの利用状態の違い、コモンスペースの評価、緑の管理・手入れの 参加方法や頻度によって異なる（図16）。コモンスペースをよく利 用する人、コモンスペースの評価が高い人は緑を肯定的に評価して いる。緑の管理参加頻度が多い場合や自主参加である場合に肯定的 な平価が多い。

このようなコモンスペースの緑に対する評価の違いは「緑による 被害・迷惑意識」にもっと明確に表れている（図17）。居住者がコ モンスペースに緑があり、それにより「落集が落ちてくる」「枝が はりだす」「病虫害が発生する」などが起こり、「被害・迷惑を受 けた」という人が約 2割、「そこまでいかなくても気になることが ある」という人は約半数である。このような「被害・迷惑を受けた 之感じる人は、コモンスペースに緑が多い場合に限らない。近隣つ きあいによる違いがみられ、近隣つきあいが親しい場合には「被害 ・迷惑を受けた」と感じることが少ない。

\section{3 䠈の管理への参加意向（図18）}

緑の管理によるコミュニティ形成の状態として「自分たちの共有

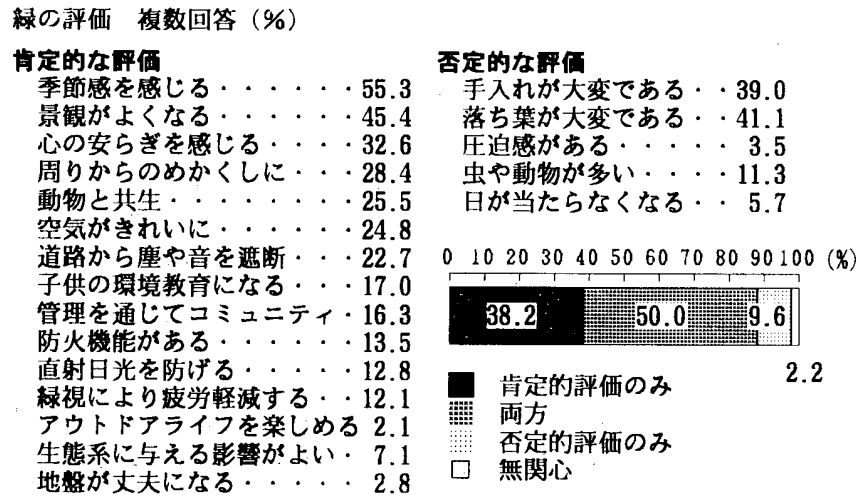

図15.コモンスペースの緣の評価 ।

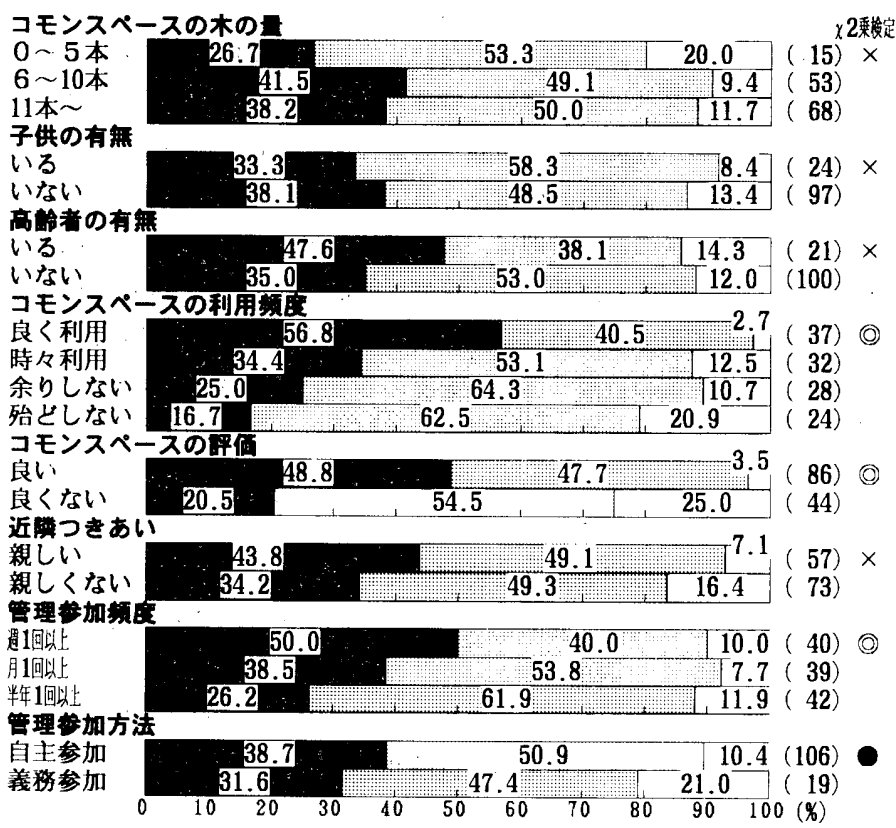

口肯定的評価 !両方之も 口否定的評価・無関心

$\chi 2$ 乗検定に危険率1.0\%で有意な差が見られるもの○、危険率5.0\%は@、 10.0\%はO、25.0\%は $\triangle$ 、危険慗25.0\%でも有意な差が見られないもの

図16.コモンスペースの绿の砰価川 一㕰価の規定要因一

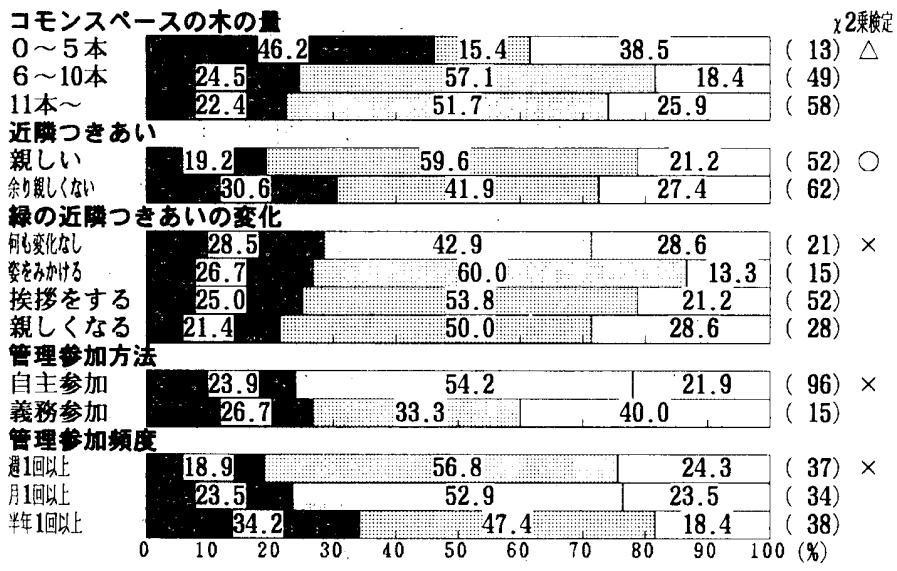

被害・迷惑がある 図になる 口気もなし $\chi 2$ 乗検定に危険率 $1.0 \%$ 有意な差が見られるもの○、危険率5.0\%は、 $10.0 \%$ ○、25.0\%は $\triangle$ 、危険㽜25.0\%でも有意な差が見られないもの×

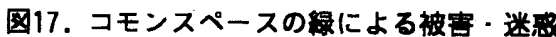




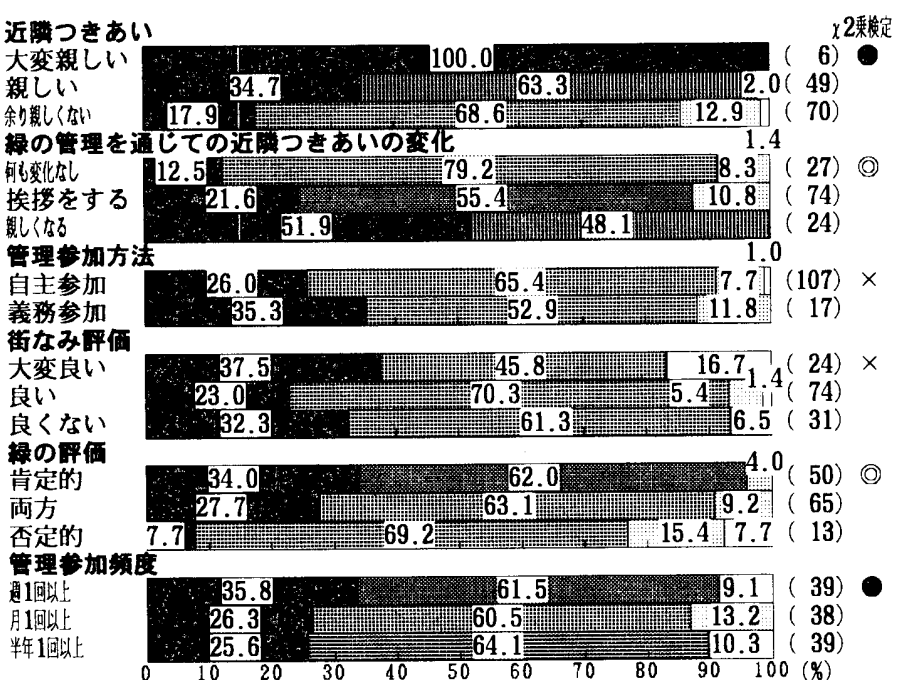

積極的に参加する 洲清掃などは参加する 費用角担はする 口何ししたくない

$\chi 2$ 乗検定に危険率1.0\%で有意な差が見られるものの、危険率5.0\%は、 10.0\%は ○、25.0\%は $\triangle$ 、危険率 $25.0 \%$ も有意な差が見られないもの

\section{図18.コモンスペースの縞の管理参加意向}

の財産である緑の手入れ・管理を居住者がともにしていこうという 参加意向があるのか」という目標の共有化の視点からみる。

「共有空間の緑の管理の参加意向」として「積極的に参加する」 は約 3割、「草刈り・清掃などに参加する」は約 6割で、公共空間 の緑の管理参加意向に比べる之高い10!。コモンスペースの緑の管 理への参加意向は、睍在の緑の管理参加方法、街なみの評価によっ て明確な違いはみられない。居住者が緑を現在どのように考え、ど の程度手入れを行っているのかによっても管理参加意向は翼なるが、 緑の管理を通じての近陆つきあいの変化、近腾つきあいの状態によ って参加意向が異なる。

このようにコモンスペースの緑の管理参加意向は居住者佃人の感 情といった態度による影䁈もみられるか、近腾つきあいなどの居住 者集四の態度による違いがみられる。

\section{5. 桔諭}

戸建て住宅地におけるコモンスペースの緑とその管理を通じての 街なみとコミュニティへの影䇴について、コモンスペースを共有空 間として集合駐車場を中心とした広場でつくられた場合をとりあげ てみてきた。

共有空間であるコモンスペースの緑は整備するだけでは居住者の コミュニティ形成にも、街なみ形成にも寄与しない。それが良好に 管理されてはじめて街なみやユミュニティの形成に寄与する。

コモンスペースの緑の管理方法は一部業者に委託することもある が、居住者主体で進められている。そして、それが良好に管理され るか否かは第一に粶の整備状態（木の量）による違いがある。第二 には、管理方法として業者委託しているか否か、コモンスペースを 全体所有による全体管理か、腾接住宅所有による腾接住宅による個 別管理かによる違いよりも、管理への居住者参加の機会の多さによ り異なっている。第三には緑の管理状態は居住者佃人の街なみ平価 や管理負担感といった考えや意向の影箄を受けにくい。そして第四 には居住者集村としての態度、つまりコミュニティの状態により異
なっている。

この場合のコミュニティの状態とは、近腾つきあいの状態といっ た居住者間のつながりかたもあるが、共有空間の緑を「共有」の価 值としてみるかいなかという価値の共有化、そしてそれを共に良好 に管理していこうという目標の共有化も含めたものである。

このようなコミュニティは、コモンスペースの共同利用やどのよ うな形態であれ共有の緑の手入れに参加することを通じて育ってい る。居住者は緑の手入れなどの管理を通じて、居住者相互の交流と 価値の共有化、目漂の共有化を形成している。居住者相互の交流之 いったコミュニティを形成することで、さらに共有の緑、共同の管 理に理解を樑め、これからの管理参加の意向が高まっている。それ により粶が良好に管理され、良好な街なみが形成されている。

このように共有の緑とその管理は現在の都市社会のコミュニティ を形成するきっかけとなっている。

注

1)計画的戸建て住宅地でのコモンスペースの導入は、1982年の守谷 地区 (茨城県北相馬郡守谷町 / 住宅・都市整備公団) や高須二工 一タウン（福岡県北九州市／高須士地区画整理組合・宮勝橫建築 研究所設計）などから始まり、現在全国で 100 以上の事例がある。 そのうち、コモンスペースが共有空間となっているものが多い (参考文献 1 )

2) 集合住宅予定地の計画変更に伴いコモンスペースのある戸建て住 宅地がつくられることもあるが、最近では土地が持つ不利な条件 を何とか積極的に利用したいとの意向からコモンスペースが導入 されることも多い（参考文献 2.3 )

3）モンスペースは、「区画内道路」「広場・小公園」「集合駐車 場」としてとられることが多く、その他、集会所などがある（参 考文献 1 )

4)コモンスペースは共有空間、専有空間、公有空間としてつくられ る。共有空間としてつくられたコモンスペースは、小公園や広場、 区画内道路、集合駐車場が多いが、同様の架間形態であっても共 有にせず、公有や尃有の場合もある。

5)参考文献 1 〜 3 に示す

6)態度とは考え方や行動の頓向を表すものである。

7) ユミュニティの定義は多々あるが、概ね共通した概念として「地 域住民の相互作用」「共通の目䧣之規範」にま之められることか ら、「地域住民の相互作用」として「近陪つきあい」、「共通の 目標と規範」として「価值の共有化」と「目標の共有化」をみる ことにする。

8)著者は近腾つきあいには二つの段階があると考えている。第一の 段陼は居住者がお互いに知合うという認知的な近縢つきあい、第 二の段階は相互に助けあいをするなどの相互扶助的な近䧣つきあ いである。

9)緑の様々な効用及び問題は既往文献を参考にした。尚、同じ設問 で公有空間の緑及び専有空間の緑についての居住者の評価をみる 之、公有空間（保存緑地・緑地公園）については「景色がよくな る」「が安らぐ「空気がきれいになる」ことの評価が高く、 専有空間については「景色がよくなる」「心が安らぐ」「季節感 を感じる「周りからの目嗳しになる」ことの評価が高い。コモ ンスペースの緑の評価は専有瑩間の緑の評価之にているが、専有 学間に比べると「周りからの目隠しになる」ことの評価が高い。

10）公共空間の緑の参加意向については「積雷的に参加する」は 1 割もなく、「草刈り・清掃に参加する」をあわせて、䄪 6 割であ る。この結果と比較すると居住者の共有空間であるコモンスペー スの緑の管理への参加意向は高い。

参考文献

1)扸藤広子・八木澤壮一：共有地のある戸建て住宅地の特性と評価 都市住宅学 第15号 P.120 P.125 1996

2)齊藤広子・八木澤壮一：共有地を積極的に取入れた戸建て住宅地 の住噮境とその管理についての居住者の評価 都市住宅学 第18 号 P.90 P.98 1997

3）茾藤広子：共有地にある戸建て住宅地の管理についての居住者の 評価一共有地の主な用途からみた評価の違い一都市住宅学 第 19号 P. $69 \sim$ P.74 1997 